\title{
The First Ten Years of Kim Jong-Il's Economic Policy: Changes and Future Direction of North Korea's Economic Policy
}

\author{
CHONG-RYEI. BAF
}

What will the North Korean economy look like a decade from now? Ever since North Korea's implementation of its Economic Management Improvement Measures in July 2002, a wide range of views have bern woiced with regard to the future dircction of the North Korean economy. This paper discusses what changed and what remained the same during the ten years since the death of Kim Il-Sung in July 19\%4, after which North Korea began trying to change its aconomy in accordance with its own version of socialism. The current state of the North Korean economy makes certain things clear. Difficult though it may bc to predict how the quantitative aspects of the North Korean cconomy will change, there is general agrecment that it will increasingly become market-oriented. However, there is no agrecment on the pace of transition. Will it be a radical bang or a gradual transformation or a third-way. The future direction of the North Korean economy will become more evident over time.

Keyuords: Inter-Korean Basic Agrcement, Rajin-Sunbong Free Economic Trade Zone, Economic Management Improvement Measures, sunshine policy, six-party talks

Direct all correspondence en Chong-Ryel Bae, Serior Research Fellow, The Export-Import Bank of Korea, 16-1 Yeouido-dong, Yeongdeungpo-gu, Seoul, 150-996, Korca; 'J'd: 82-2-377)-6709; E-mail: khsber $(\underline{a} ;$ chollian.net 


\section{INTRODUCTION}

I

n the aftermath of North Korea's implementation of its Economic Management Improvement Measures in July 2002, many opinions have emerged with regards to the future direction of the North Korean economy. On May 162004 , Ta Kung Pao, one of the oldest dailies in China, carried a report in which it analyzed the possibility of North Korea adopting a markct economy. The three main arguments contained in this report can be summarized as follows: 1) Given the timid nature of the North's reforms and opening to the oursidc world to date, a market economy system can hardly be expected 2) morcover, ever if the North earnestly implements reforms, several significant obstacles will remain before a market economy can be introduced 3) the North's successful implementation of reforms will at the very least mean that a return to the ways of the past is impossible (KOTRA 2004). Various opinions on the future direction of the North Korean economy have emerged within Korea as well; with these opinions ranging from those who argue that the cutrent changes will inevitably lead to the introduction of a market economy system, to those who maintain that the ongoing changes in North Korea will not bring about any long-term structural changes (Jeong 2004; Park 2004; Lim and Jcong 2004; Cho 2001). In which direction is North Korea's economy heading? Can North Korea follow China and Victnam's lead and effectively intruducc a market economy system? Or will the North follow the "Big Bang" approach adopted by the USSR and Eastern Europe as they tried to reform their planned economic systems? As the number of operarional spaces in which a market economy can function has increased, the hope has grown in some quarters that North Korea will indeed proceed with the introduction of a market economy. However, the overarching problem with this line of thought is that it does not sufficiently take into account the economic system that has been in place in the North for the last 50 years. In other words, can the software used to manage the economic system, which has functioned alongside a planned cconomy system that has been in place for some 50 years, casily be changed? China, a country which had a planned economy systern in place for some 30 yeats, was able, as a result of the reform and opening up policy it adopted at the end of the 1970s, to successfully move towards a market economy. On the other hand, the USSR, which functioned under a planned economy system for some 70 years, rapidly moved towards a market economy at the end of the 1980's as a result of its adoption of a "Big Bang" approach. This change, although very rapid, has not been accompanied by a concurrent understanding of the implications of a market cconomy among the general population of these countries.

The future direction of the North Korean exonomy will become more evident as time goes by. Nevertheless, it is clear that the current economic situation in North Korea and the changes in the external envirunment have led to these changes in the North's economic structure. Since the death of Kim Il-Sung in July 1994, North Korea has attempted to change its economy in accordance with "our-style of socialism." 
How should the first 10 years of the Kim Jong-Il regime be evaluated? What consistencies and changes have been recorded during this period? How will North Korea change in the future? While these are not easy questions to answer, this paper nevertheless artempts to do so in order to contribute to the understanding of the issues surrounding these questions.

\section{DEVELOPMENT OF THE NORTH KOREAN ECONOMY UNDER KIM JONG-IL}

\section{Kim II-Sung's Economic Iegacy}

Before any discussion or evaluation of the North Korean economy under Kim Jong-Il can be carried out, the economic legacy left behind by Kim Il-Sung must first be addressed. Such an analysis is important because the economic legacy left behind by Kim Il-Sung became the basic foundation for Kim Jong-ll's own economic policy: and has also acted as one of the most important factors complicating efforts to make certain changes to the North Korean economy.

Kim Il-Sung's stylc of economic construction, which picked up speed with the Chollima Movement launched at the conclusion of the Korean War in 1953, was at the outset quite successful. This can be ascertained by the fact that the goals of the 1st Five-year Economic Plan, from 1956 to 1960, were achieved a year early. However, with the abandonment of its Six-year Economic Plan for 1971 to 1976 in August 1975, North Korea found itself at a crucial juncture (Bae 2003). During this period, rwo changes in the regional landscape began to seriously threaten the North Korean economy, which had by this point become internationally banknupt: First, the North's defeat in its economic compecicion with South Korea, which had been a very heated one during most of the 1970s, led to the establishment of a new relationship between the two Koreas, and to several economic problems for North Korca. Second, North Korea found itself increasingly pressured to prepare an adequate response to Deng Xiaoping's reform and opening policy launched at the end of the 1970s.

At this point, North Korea chose to move in three different directions. First, it decided to attract foreign investment, a move accompanied by the taking of such steps as increased emphasis on the development of international trade in the 2nd 7-year economic plan (1978-1984) and in the passing of the Joint Venture Law (September 8, 1984). Second, North Korea began to participate it inter-Korean exonomic talks (November 15, 1984), responded positively to President Chun Doo-Hwan's proposal for inter-Korean trade and counomic coopcration, and accepted the South's offer to provide commodities and technologies to the North (August 20, 1984). Third, the North also rcinforced the Yonbap-Giupso - which combined companies engaged in similar industries in a larger unit (Nakagawa 2003) - and strengthened the self-account- 
ing system ( $\mathrm{Kim} 1990,352-364,426-483$ ). However, as North Korca remained weary of launching reforms similar to those undertaken by China, the degree and scope of its reforms remained well below global standards. Moreover, the economic dialogue between North and South Korea broke down afrer the $5^{\text {th }}$ round of talks (November 20, 1985). The North's policy of attracting forcign investment, which had been designed to acquire capital from the West, essentially became nothing more than a joint venture with Chochongryon - the General Association of Korean Residents in Japan - a denoucment which left many North Korean economic managers frustrated. ${ }^{1}$

This failure to reforn the North Korran economy during the 1980s and the concurrent epochal changes in the external environment, namely the unification of Germany, and the collapse of the Soviet Union and the East Furopean socialist block, had wide-ranging repercussions for the North Korean economy. These included, first and foremost, the loss of international markets. In fact, as a result of its conclusion of a new trade agreement with the Soviet Union in November 1990, which stated that from then on all payments had to be made in hard currency, and of a similar agreement with China in January 1992 that brought all barter-based trade to an end-agreements which were rendered necessary by the changes that had been wrought to the USSR and Eastern Europe's economic structure-North Korea lost about $70 \%$ of its international markets. Sccond, this period also witnessed the onset of North Koreas negative growth rates. In addition to this decrease in international trade, the near-curtailment of the Chinese and Russian shipments of crude oil and food aid also severely damaged the Norch Korean economy. This led to a growing lack of resources and raw materials essential to running the North Korean economy, which in turn led to a significantly lower output on the part of North Korean factories. Third, signs of a collapse of the food distribution system, one of the fundamental functions of a planned economy, also began to appear during this period. As a result of the growing problem of acquiring food from abroad, a two-meal a day campaign was launched from 1992 onwards. This situation was even worse in the northeast of the country where the food distribution system had already experienced paralysis on numerous occasions (Natsios 1999, 5).

Kim Il-Sung, recognizing the seriousness of the situation, adopted various measures: 1) Officially recognizing the failure of the $3^{\text {rd }} 7$-year economic plan, Kim II-Sung declared an agriculture, light industry, and foreign trade-first policy as the economic straregy to be implemented during the buffer period (1994-1996) (December 8, 1993: 'l'he 21st Session of the 6th-term Party Central Commitree) (Kim 1996, 272-290) 2) moreover, in order to normalize the North's relations with the South as well as with the international community, which had gone from being promising in the aftermath of the signing of the lnter-Korean Basic Agreement (February 19, 1992) and Additional Protocol (Septomber 17, 1992) to being seriously strained by the North's withdrawal from the Non-Proliferation Treary (NPT) (March 12, 1993), Kim Il-Sung agreed to restart talks with former U.S. President Jimmy Carter, (June 18-19, 
1994) and to hold a North-South Korean Surmit (June 28, 1994) 3) in addition, Kim Il-Sung also instructed that the Rajin-Sonbong Free Economic Trade Zone be rapidly developed (June 14, 1994) (Bae 2000; Kim 1996, 453-461).

\section{The North Korean Economy Under Kim Jong-Il}

If we accept the premise that the three main criteria used to evaluate the changes that have taken place within North Korea should be domestic, inter-Korean, and international developments, then the development of the North Korean economy in the aftermath of Kim Il-Sung's death (July 8, 1994) can be separated into three periods. The first of these periods spans from Kim Il-Sung's death in July 1994 to Kim Jong-Il's inauguration as the General Secretary of the Korean Workers' Party in October 1997 (1994-1997). This period can be referred to as the continuation of Kim Il-Sung's economic legacy. Meanwhile, the second period runs from Kim Jong-Il's inauguration as the General Secretary of the Korean Workers' Party to the implementation of the Economic Management Improvement Measures in July 2002 (1997-2002) and can be labeled as the preparatory stage of economic reform. Finally, the third period begins with the onset of the Economic Management Improvement Measures (2002-present), a period which will be referred to herein as the implementation stage of economic reform.

(1) The Continuation of Kim Il-Sung's Economic Legacy (July, 1994 - October, 1997)

In the aftermath of Kim Il-Sung's death Kim Jong-Il was faced with the arduous task of either upholding or abolishing his father's cconomic legacy. Unfortunately for Kim Jong-Il, in reality no such option was available to him as the North Korean economy was by this point for all intents and purposes bankrupt (O 1995, 47-48; $\operatorname{Kim} 1996,474-490$ ) and the collapse of the food distribution system that had started in the northeast began to spread (Natsios 1999, 14). As such, Kin Jong-Il's decision to leave all of his father's policies in place during this first period, officially explained away as due to the observance of a three-year mourning period by the younger $\mathrm{Kim}$, was all but predetermined by external factors.

First, Nurth Korea attempted to ease its energy and food problems, which were at this point the most urgent issues facing the North Korean economy, through the settlement of the fust North Korean nuclear crisis. The Geneva Agreement (October 21, 1994) allowed North Korea to, from 1995 onwards, assure itself of 500,000 tons of cude oil and 1 million tons of grain annually from the U.S. and the international community (Natsios 1999, 8). Moreover, during this period Kim Jong-Il actively pursued the development of the Rajin-Sonbong Free Economic Trade Zone while keeping in place Kim Il-Sung's agriculture, light industry, and foreign trade-first policy (Kim 1994, 11-23). However, two limitations arose to hinder the development of the North Korean economy at this time: the socialist overtones of this agriculture, 
light industry, and foreign trade-first policy (Kim 2000, 8-9), and the adoption of a strategy for attracting foreign investment that was based on coopcration with the Western world without any concurrent improvement in inter-Korean economic relations (Bac 1995, 22-27). In the end, this economic strategy proved to be a disaster as negative growth rates became the norm; a massive number of people died from starvation (Natsios 1999, 1); the government's control over population movements was paralyzed, and the collapse of the central distribution system caused a concurrent drop in industrial output as well as chronic inflation. Further compounding matters, the goverument's hoped-for foreign investment in the development of the Rajin-Sonbong zone never reached expectations (Bae 2000).

During this period, some signs of change began to appear on the horizon:

First, Kim Jong-Il's adoption of a military-first economic strategy tesulted in stretigthening his leadership over the military (Kim 2000). In reality, it was only natural that North Korea developed its heavy-chemical industry during its competition with the South, as this could be used to build munitions. This military economy, which accounted for $30 \%$ of the overall budget at the end of the $1960 \mathrm{~s}$, grew to account for in excess of 60\% of total industrial production by the mid 1990's (Bae 2003, 157). Accordingly, the munitions industry became the last stronghold that North Korca could mobilize to rebuild its economy.

Second, experimental reforms, alchough limited to the Rajin-Sonbong Free Economic 7one, began to be implemented. In fact, new legal mechanisms were put into place and cnforced from June 1, 1997 unwards that included the adjustment of the exchange rate (from 2.21 won to 210 won to the dollar), implementation of a flexible exchange tate system, application of market prices to certain products, and the granting of the permission for market economy activities to take place in certain specified sectors (food and accommodation industry, food processing industry, repair and maintenance services, handicrafts industry, as well as a few other industries) (Bae 2000, 348).

Third, as a result of the ongoing economic difficulties non-socialist economic phenomena, such as the emergence of farmers' and underground markets, began increasingly to pop up as an alternative to the moribund formal econonny. Although estimates of the size of this informal economy vary greatly (Park 2002; Nam and Mun 2000)2, all igree that its influcnce increased grcatly from the middle of the 1990s onwards.

\section{(2) Preparatory Stage of Economic Reform (October 1997-July 2002)}

Upon being officially named to the post of General Secretary of the Korean Workers' Party on October 3, 1997, Kim Jong-Il immediately began to tackle economic issues (Kim 2000, 253-273, 274-287). Despite an overall continuation of Kim Il-Sung's economic policies, Kim Jong-Il also began to establish the foundation needed to gradually implement his own independent policies. In other words, although Kim Jong-Il's declaration of the need to independently construct the national cconomy whilc devclopirg a strategy to reestablish socialism and re-launch the Chollima 
Movement, which Kim Il-Sung had used to build the economy during the 1950s, can be regarded as a return to the past, Kim's inauguration as the Chairman of the National Defense Commission, the modification of the Constitution, the growth of independent economic development, and the adoption of a military-first policy by the Korean Workers' Party (KWP), should be seen as having sown the seeds of changes that were carried out in a gradual fashion.

The first task to which the newly elected General Secretary of the KWP turnod his attention was the construction of a system that could be used to temporarily mobilize the military's economic resources for the rebuilding of the cronomy. The first signal of this strategy camc during Kim's visit to the Jagangdo area in January 1998 (Bac 2003; Kim 2000, 393-41 1; Masan 2001). In this regards, Kim's reclection to the post of Chairman of the National Defense Commission, which came immediately after the North's first launch of the Daepodong missile (August 31, 1998), and the modification of the Constitution (September 5, 1998) were meant to announce to the international community that the North had adopted a military-first system in which the military's economic resources would be mobilized to rebuild the North's economy.

The next change occurred as a result of the changes that took place in Northeast Asia following the outbreak of the bast Asian financial crisis in July 1997. Here, two strcams directly related to the North Korean economy emerged in connection with these larger developments: One was the testoration of the North's traditional relations with China and Russia, relations which had been strained since the beginning of the 1990s. The other was the North's positive response to the Sunshine Policy launched by the Kim Dae-Jung government. This positive response was premised on Kim Jong-Il's belief that his participation in an Inter-Korean summit could help achieve a breakthrough for the North Korean economy, which proved to be quite astute as Kim Jong-Il's successful summit diplomacy with China (May 29-31, 2000), South Korea (June 13-15, 2000), and Russia (July 19, 2000) did in fact positively influence the North Korean economy. In particular, the inflow of cconomic resources such as encryy, food, and hard currency from China and South Korea allowed the North to record positive growth rates from 1999 onwards, and to improve the industrial output of its main industries.

Howcver, due to the contradictory results of the policies implemented during this period there has been much confusion as to how to evaluate the changes that took place at this time. This period saw the North's links with the global financial sector be severed as a result of the bankruptcy of Peregrine Investments Holdings Limited, the parent company of the Peregrine Daesong Development Bank, and of the ING Northeast Asian Bank's decision to withdraw from North Korea after the outbreak of the East Asian financial crisis (Bae 2000, 362). Moreover, the construction of the Rajin-Sonbong liree Economic Trade Zone actually ground to a halt during this period, all of which represent the red lights faced by the North in its efforts to gair access to international markcts during this period. 
However, the North's success in getting the L.S. to ease a second sct of econorric sanctions (September 17, 1999) (Korean Central News Agency 2000), and in establishing diplomatic relations with several European nations can be construed as some of the green lights that helped to further invigorate North Korea's reform and opening policy.

On the other hand, the constant debare over the North's weapons of mass destruction, a debate which was further exacerbated by the North's launch of a Daepodong missile as part of its military-furst policy, cmerged as another red light for the North's economic opcrning effort, with the Bush Administration's growing concern over the spread of weapons of mass destruction placing the North squarely at odds with the U.S. Conversely, the North's growing emphasis on scientific technologies, pragmatism, and on the need for new thinking based on the dual slogan of the drive to axhicve reform \& opening and practical socialism (Chosun Shinbo 2002), which was first announced during Kim Jong-Il's visit to Shanghai (January 15-20, 2001), represents another green light in terms of the North's opening up of its economy to the outside world.

Unlike the confusion that surrounded the North's international and domestic exonomic policies, the changes that occurred in inter-Korean economic relations during this period were evident. While economic relations between the two Koreas appeared to be strained at the beginning of this period, in latge part because of the North's rcfusal to allow Suuth Korean companies to enter the Rajin-Sonbong area (Bac 2000, 336-369; Bac 2003, 168-169), the donation of 500 heads of cattle to the North, which were transported ovet the heavily fortified DM7. (June 16-23, 1998), helped to facilitare the holding of a moeting between Kim Jong-Il and the honorary chairman of the Hyundai Group Chung Joo-Young, (October 30, 1998); a meeting which in turn helped to put North-South economic rclations on track. However, the most significant development during this period was the signing of the June 15 Joint Declaration during the Inter-Korean Summit of June 2000. This agreement marked the onset of the North's strategy of using the gains made in inter-Korean cooperation to attract foreign investment; a stracegy based on improving inter-Korean economic relations and ending the hostile relationship of the last 50 years in order to facilitate the Nurth's opening up of its cconomy to the outside world.

\section{(3) Implementation Stage of Economic Reform (July 2000 -)}

Many of the difficulties faced by North Korea during the preparatory stage of economic reform were dealt with in the Fconomic Management Improvement Measures that were implemented in July 2002. Moreover, North Korea's new found notions of practical socialism were also evident in the announcement of the establishment of the Sinuiju Special Administrative District (September 19, 2002) and in the passing of a law making the Geumgangsan area a tourist district (November 13, 2002); which was followed by the passage of a law designating Gaeseong as a special economic zone (November 20, 2002). This practical socialist policy was designed to creace diverse operational spaces where both the planned and the emerging market cconomy 
could function, with the market's operational space restricted to certain arcas. In other words, North Korea has adopted a policy of maintaining its socialist economy by bringing about a pragmatic reorganization of the systern. Meanwhile, North Korea has decided to introduce a capitalist system in special economic areas such as the Sinuiju Special Administrative District.

Domestically, North Korea has also implemented significant changes in its policies on price, wage, and corporate management. 'Ihese have included: 1) the readjustment of prices, 2) formation of pragmatic economic development plans, 3) expansion of material incentives, 1) increase in the number of items subjected to market prices, 5) and the decrease in the overall financial burden. All of these changes have been based on the normalization of the state's development plan (Cho 2004, 7; Kim 2004, 39-41). In particular, the massive incrcase in prices, which has sometimes reached as high as 25 -fold, and this even when exchange rates are adjusted, has been the first such drastic price increase in the 50 -year history of Norch Korea. In addition to the above-mentioned changes in long-standing socialist principles, another limited change that has taken place has been the primacy given to the development of the defense industry over the agricultural and light indastries (Chosun Shinbo 2003). In other words, although the military's economic resources have been used to promote chis so-called practical socialism, in the overall North Korean cconomic structure military indicators continue to play a larger role than public ones.

This period has also seca dramatic dianges in the international environment. Although the plan to turn Sinuiju into a Spccial Administrative District along the same lines as Hong Kong was announced soon after the DPRK-Japan Pyongyang Declaration of September 172002 , this announcement was met with disinterest from the West who by this point had lost faith in the potential of this project following the revelation of the North's pursuit of secret uranium-based nuclear program, which was made public after U.S. special envoy James Kelly's visit to North Korea (October 3-5, 2002), and the arrest of the man- Yang Bin- whom North Korea had designated as the First Ministet of the Sinuiju Special Administrative District in China (October 8, 2002). Nevertheless, North Korea's willingness to reform and open up its markets during this period went well beyond most observers' expectations. North Korea's withdrawal from the Non-Proliferation Treacy (January 10, 2003) following KEDO's decision to stop providing crude oil (November 14, 2002) to the North relegated the construction of the Sinuiju Special Administrative District to the backburner, as the North increasingly focused its energies on the six-party talks designed to tesolve the current nuclear crisis.

Despite the ebb in Japanese-North Korean economic relations, North Korea has managed to maintain positive growth rates throughout this implementation stage of economic reform. However, by far the most remarkable change that has emerged during this period has been the development of iner-Korean economic relations, with the arnount of annual trade between the two Korcas now reaching in excess of 700 million dollars. As a resule of the passing of the law making the Geumgarngsan 
area a tourist district and the proclamation of the law designating Gaeseong as a special economic zone; the official announcement of a four-point economic cooperation pact (August 20, 2003); and the basic meeting of the minds on the need to reconnect railroads and roads that has been in place since November, 2002; the inter-Korean economic relationship has become more official and institutionalized. Furthermore the Gaeseong Industrial Complex has been established during this period, with several enterprises having already begun to move into the complex.

\section{EVALUATION OF THE NORTH KOREA ECONOMY UNDER THE KIM JONG-IL REGIME AND FUTURE PROSPECTS}

\section{Signs of Change}

(1) Quantitative Aspect: Concinuation of economic difficulties and increased dependence on the outside world

A decade has passed since the launch of the Kin Jong-ll regime. How have Kim Jong-ll's policies affected the North Korean economy? Here, the economic indicators found in Table 1 clearly illustrate the achicvemonts that $\mathrm{Kim}$ Jong-ll's government has been able to bring about over the last 10 years. The government's ability to steer the economy away from nine consecutive years of negative growth towards positive growth, which has been accrued ever since Kim Jong-Il assumed full control over the government, has been nothing short of remarkable. On the other hand, as most of these economic indicators demonstrate, Kim Jong-Il has been unable to bring the economy back to where it was prior to Kim ll-Sung's death. This point is clearly evidenced by a brief look at economic indicators such as the nominal GNI, GNI per capita, size of the overall budget, coal production, gencration of electric power, fertilizer and steel production, and the size of international loans.

Despite all this, sume changes have occursed that have for the most part gronc under the radar. There are signs that North Korca has begun to increasingly participate in the international economy. As we can see from Table 1, North Korea's intemational trade, as well as inter-Korean trade, has increased since 1998, with the combined worth of such trade estimated at approximately 3 billion dollars. If the current trend continues unabatcd, it appears very likcly that North Korea will be able to once again reach the 4 billion dollars in annual trade that it usually accrued before the collapse of the socialist bloc. Furthermore, the 300 million dollars in humanitarian support a year that North Korta has received from the international community since 1997 has served to further connect the North Korean economy, led by Kim Jong-Il, to the capicalist economy. In this regards, the growing links between the North Korean economy and its Chinese and South Korean counterparts have been by far the most salient development. 
TABLE I. NORTH KORFAN FCONOMIC INDICATORS

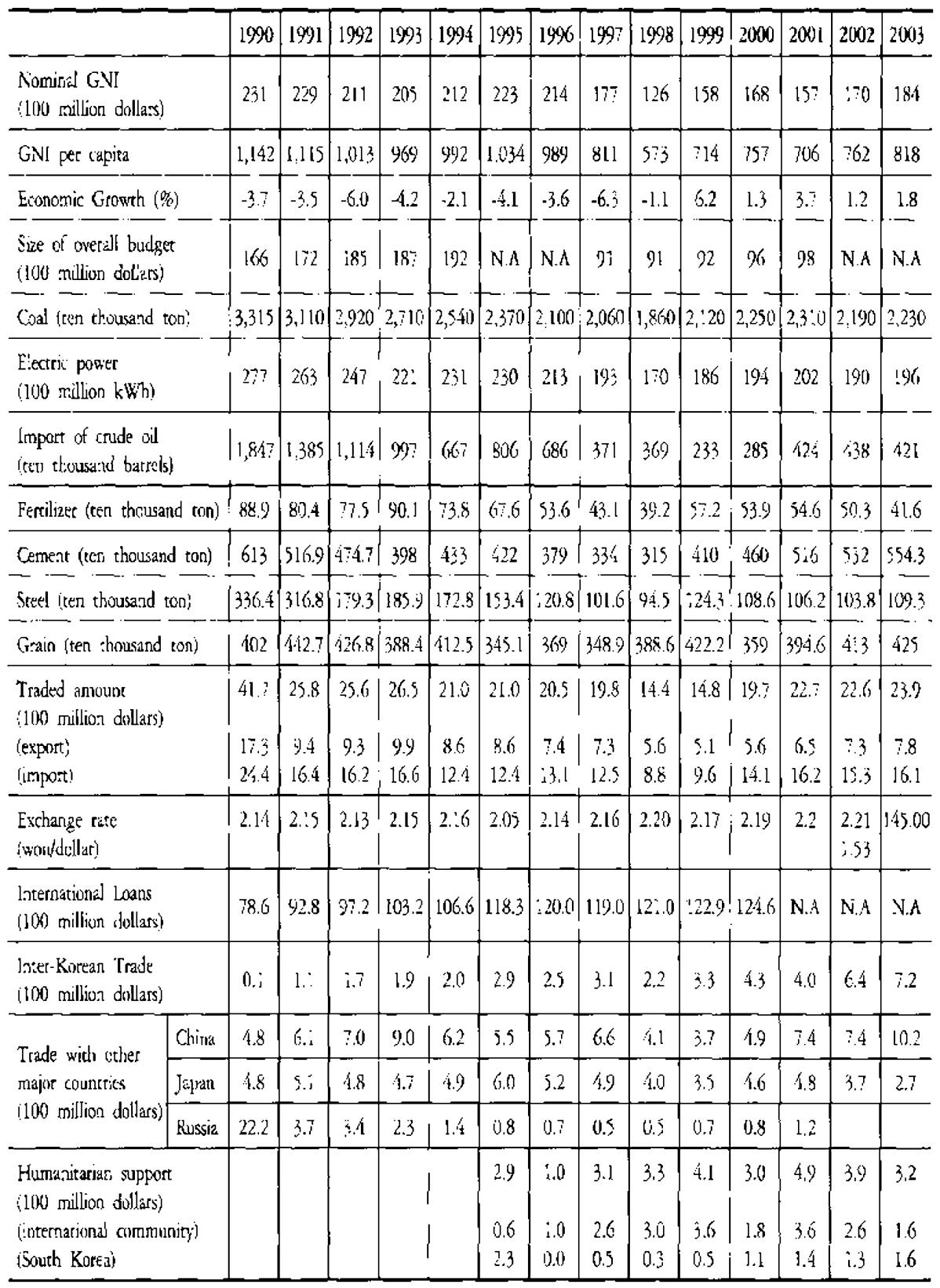

SOURCE: Miniscry of Unification, Bank of Korea.

The message parlayed by these quantitative economic indicators is quite clear: The recent recovery experienced by the North Korean economy has not been the result 
of internal factors but of external ones. Put differently, the main cause for the positive growth rates that the North Korean economy has posted over the last few years has been the increase in the amount of economic resources coming from abroad. As such, after ten years of Kim Jong-Il and his policies, the current state of the North Korean economy can be characterized as follows: While economic difficulties have continued, the growth rate appears to have gradually stabilized as a result of the increase in the North's dependence on foreign economic resources.

(2) Qualitative Aspect: Imbalance between military-first politics and the North's feform and opening policy

What have been the main factors behind the above-mentioned devclopments that have taken place within the North Korean economy over the last 10 years? Table 2 represents a summary of the North Korean economy prior to Kim Il-Sung's death, an analysis of which was carried out in section 2, and the main events that have emerged over the first 10 ycars of Kim Jong-Il's rule. In terns of the main factors that have remained largely unchanged from the Kim Il-Sung era, the following can be identified: Li.S.-North Korea relations have continued to deteriorate as a result of the second nuclear crisis; Kim Il-Sung's military-oriented politics have given way to Kim Jong-Il's military-first politics; and the KWP's ruling principles have remained all but unchanged from what they were during the Kirn Il-Sung cra.

Then what has changed? First of all, the ruling system has changed from being one of direct KWP rule to one where the KWP now indirectly controls the country through the military. This change has in all likclihood been precipitated by Kin Jony-Il's perception that; given the growing paralysis of the North's planned economy system as a result of the ever-widening economic hardships faced by North Korea, and the widespread international belief during the period following Kim Il-Sung's death that North Korea was abour to collapse; the only means of overcoming the domestic and international problems faced by the North was to rely on the military and the military's economic resources.

Second, the scope and intensity of the North's reform and opening policy has changed as well. What began to a certain degree as a domestic reform, the construction of special economic zones, has over time developed into a drive to build Hong Kong - style special administrative districts. Moreover, the North has sought to develop inter-Korean economic relations - a move which has already yielded such tangible results as the Geungangsan tourism project and the Gaeseong Industrial Complexas a means of increasing its participation in the global markct. Even morc cncouraging for the North is the fact that the changes that have been wrought to the North Korean economy as a result of the implementation of the Economic Management Improvement Measurcs are expected to positively influence the construction of such special economic zones in the following manner: 


\section{Tabie 2. Main Developments Pertaining to the North Korean Economy DURING THE FIRST 10 YeARS OF THE KIM JONG-IL Regime}

\begin{tabular}{|c|c|c|c|c|}
\hline & \multirow[b]{2}{*}{$\begin{array}{l}\text { Kim ll-Sung's } \\
\text { econurwic legacy }\end{array}$} & \multicolumn{3}{|c|}{ Main econumic policies during the firse decate of the Kim Jong-II reggins: } \\
\hline & & $\begin{array}{l}\text { The continuation of } \mathbf{K i m} \\
\text { Il-Sung's econonic legacy } \\
(1994.7-1(k) 7.9)\end{array}$ & $\begin{array}{l}\text { Preparatory stage of } \\
\text { ecminomic reform } \\
(1997,9-2002.7)\end{array}$ & $\begin{array}{l}\text { Implementation stage of } \\
\text { economic reform } \\
(20(1) 2, \quad:-)\end{array}$ \\
\hline $\begin{array}{l}\text { Oherall } \\
\text { ecsncmic } \\
\text { situarion }\end{array}$ & 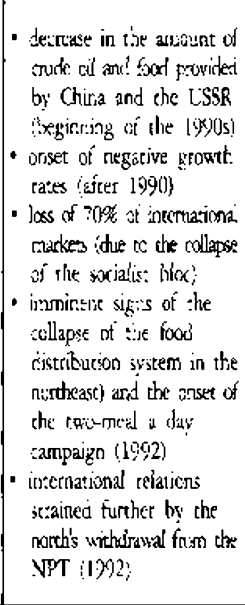 & 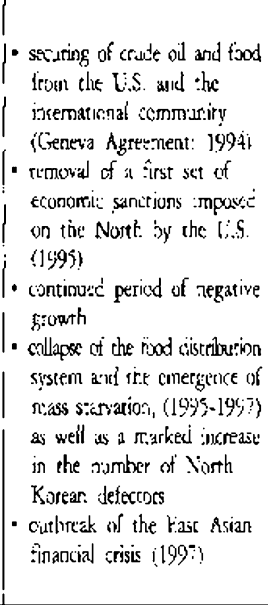 & 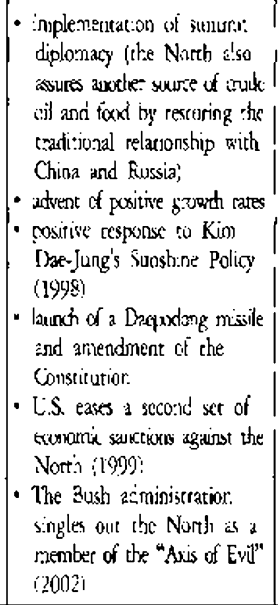 & 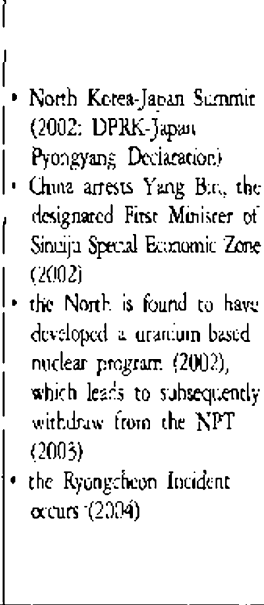 \\
\hline $\begin{array}{l}\text { Dormestic } \\
\text { develonmears }\end{array}$ & 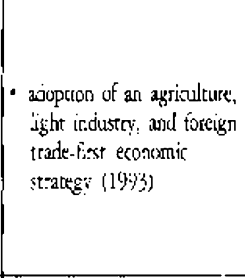 & 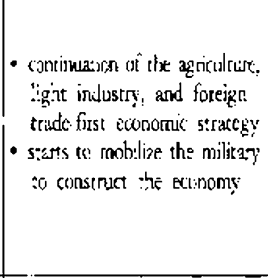 & 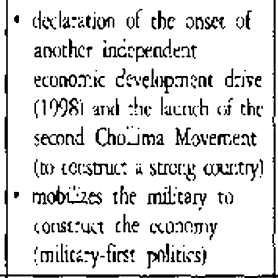 & 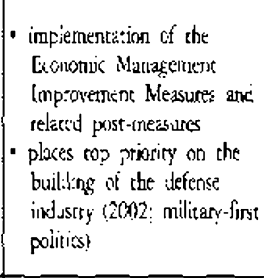 \\
\hline $\begin{array}{l}\text { Intecrationaj } \\
\text { develingments }\end{array}$ & 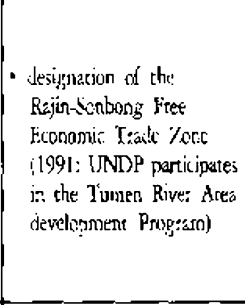 & 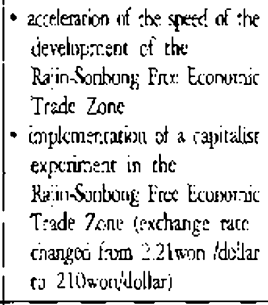 & 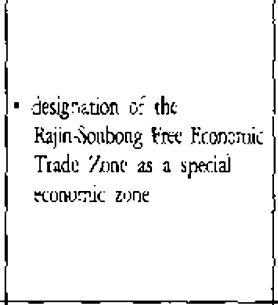 & 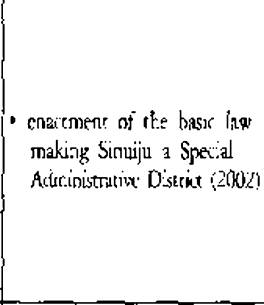 \\
\hline $\begin{array}{l}\text { Inter-Konean } \\
\text { erormic } \\
\text { sooperation }\end{array}$ & 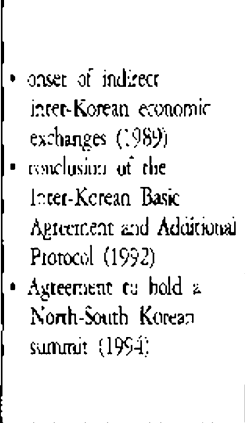 & 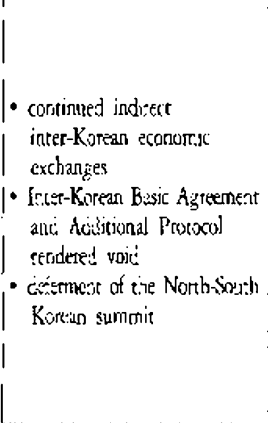 & 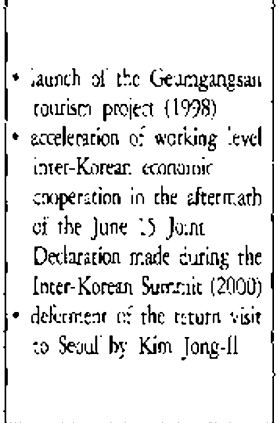 & 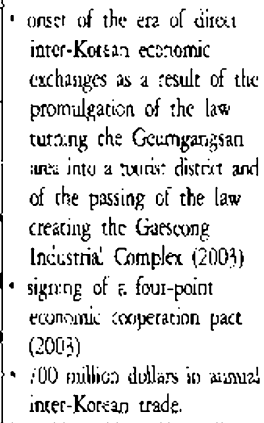 \\
\hline
\end{tabular}


First, the North's ability to link its economy with the global one has been greatly increased by the easing of the inflation gap. As mentioned ahove, prior to the implementation of the improvement measures the North had religiously abided by a fixed price system that based all prices on the cost of industrial goods such as coal; meaning that no major readjustment of prices had been undertaken in 50 years. The same was true with regards to the exchange rate, which was manipulated to represent international prices. Therefore, inflation spread at a rapid pace as the gap betweca the regulated domestic prices and international market prices, and berween the exchange rate and international rates, grew exponentially. This inflationary phenomenon created circumstances which made it difficult for foreign enterprises wishing to open joint venture companies with the North, or to enter the domestic market of North Korea through normal channels, to achieve their objectives. Following the implementation of the Economic Management Improvement Measures, price are now based on the food price index, which is much more sensitive to variations in supply and demand. Even though inflation has cmerged once again, the gap has been narrowing compared with the inflation rate before the announcement of the EMJM ( $\mathrm{Km} 2003,60$ ).

Second, as North Korea has become further integrated into the market economy system, it has found it increasingly easier to introduce capitalist management methods. Although a partial market economy, in the form of government-authorized farmers markets, did exist in some sectors of the economy before the implementation of the Economic Managenuent Improvemenr Measurcs, a majority of the trade that went on during this period was carried out in underground markets, with the state increasingly encouraging the growth of these black markets as a means of partially overcoming the prevailing economic difficulties. However, since the implementation of the Economic Management Improvement Measures various steps have been taken to increase the role of the market cconomy in legal spaces. These steps have included the following: 1) 'The expansion of material inducements in the form of increased autonomy and incentives for the managers of organizations and enterprises 2) the legalization of the trade of industrial proxlucts in markets 3) the granting of permission for enterprists to participate, although only in specified sectors, in the market 1) and the granting of permission for cooperarive farms to engage in small-scale trade with China. Since the implementation of the Economic Management Improvement Measures, North Korea has aggressively pursued the development of the Graeseong Industrial Complex. Moreover, the advent of an internationalized wage system, the increased ability of corporations to autonomously hire and fire employees as the see fit, and the implementation of an incentive system, can all be linked back to the North's introduction of a capitalistic management system.

Third, the participation of North Korea's general population in the market economy has increased as woll. As a result of the Economic Management Improvement Measurcs, Kim Jong-Il's order that the standard distribution system be done away with has officially become law. To date, the main problem has been that workers' wayes have not been able to keep pace with the concurtent increase in prices that has been 
brought about as a result of the Economic Management Improvement Measures. Consequently, although it had already become a serious problem by the time the issue of mass starvation emerged during the mid 1990s, the economic gap (Kim Woon-Keun 2003) has become even worse in the aftermath of the Economic Management Improvement Measures (Washington Post 2004). The polarization of economic classes has ironically heightened support for the introduction of a market economy in North Korea, in that the North increasingly finds itself having to expand the spaces in which the market economy can operate in order to maintain the power of the group that has gained most from the Economic Management Improvement Measures- i.e. the members of the Korean Workers' Party, military officials, and traders, who have monopolized the economic benefits of the EMIM - and to assure that those who have lost the most as a result of the implementation of the Economic Management Improvement Measures - workers - can make a living.

The problem is that the emphasis on military-first politics is reverberating throughout the North Korean economy like a boomerang in the aftermath of the Bush Administration's launch of the wat on terror. Given the fact that the positive growth rates enjoyed by the North Korean econony have in large part been due to external factors, the ongoing conflict with the U.S. and the continued dogmatic emphasis on socialist principles have limited the efficiency of North Korea's reform and opening policy. As can be seen in Table 1, North Korea's growing laments about the drop in North Korcan-Japanese economic rclations and the whirlwind speed at which inter-Korean economic cooperation has developed since 2001 (Lee 2004) can also to some degree be interpreted as another offshoot of this emphasis on military-first politics. This dilemma caused by the instability between the North's military-first politics and its desite to more adamantly pursue a reform and opening policy, has been the main factor behind the North Korean economy's present state.

\section{Future Prospects}

(1) Kim Jong-II's Economic Policy: The third way

Kim Jong-Il's economic policy, which has begun to increasingly take shape since the implementation of the Economic Management Improvement Measures, can be said to represent a third-style of socialist economy. In other words, it is neither a rapid transformation to a capitalist economy as was the case in Russia and in Eastern Europe, nor the gradually reformed socialism that China and Vietnam have adopted. Although North Korea's reform efforts date back over two decades, it is only recently that scholars have begun to pay attention to these efforts. Opinions on this reform movement have ranged from those who argue that the economic reforms undertaken by North Korat are similar to those carried out in Eastern Europe during the 1960-1970s (Cho 2004, 3; Kang 2003, 14-15; Lee 2003, 76-77), to those who maintain that although similar in spirit to the Chinese reforms cartied out from 1979-1984, the 
North's efforts to date have been too timid in nature (Park 200/4, 25). In other words, they argue that while the change that has taken place in North Korea's economic policy is sigaificant, the speed of these changes has been too slow.

In this regards, it should be noted that the capitalist experiment launched in the Rajin-Sonbong area has unfolded at a rapid rather than gradual pace. The capitalist experiment in the Rajin-Sonbong area has contributed to the construction of the Gaeseong Industrial Complex, the designation of the Geumgangsan arca as a tourism district, and to the further development of the Sinuju Special Administrative District. These second round development has been seen neither in Russia nor in China or Vietnam. Especially, the Sinuiju Special Administrative District is different from the special economic zones observed in China. The Special Central Administrative District is closer to the stanus of Hong Kong and is more independent from central administrative interventions or the KWP.

North Korea's reform and opening policy cannot be explained solely based on economic factors; rather, it has been derived from complicated political, military, socioeconomic and cultural factors, factors which include the resolution of the problems stemming from the division of the Korean peninsula; the teorganization of the Notheast Asian order; as wcll as several international and military issues, including the normalization of North Korean-U.S. relations. As such, depending on how the situation unfolds, the four special economic zoncs that have been set up in North Korea, especially the Sinuiju Special Administrative District, may very well wind up contributing to the advent of a "Big Bang" change in the North.

From a general standpoint, Kim Jong-Il has been able to weather the rampant economic problems faced by the North and successfully manage to achieve positive growth by using the growing amount of economic resources flowing in from abroad (Shambaugh 2003, 65; Cha 2004, 45). However, in order for the North to continue this juggling act, it has had to resolve the conflict between its military-first politics and its teform and opening policy. The direction that the reform and opening policy has taken since the implementation of the Exonomic Management Improvencent. Measures represents the alternative that the North has selected to resolve this conflict. In essence, this new approach has been one of separating special economic zones from regular areas. As such, while institutional changes have been made within these special zones, the overall focus has been on improving technological efficiency by reforming the system from within. This is why from the outside, Kim Jong-Il's economic policy, which is based on practical socialism, appears to be proceeding much more slowly than China's reform and opening policy. However, the reality is that this approach may very well bring about more rapid changes than China, or even, depending on how things develop, result in a "Big Bang," as mentioned earlier.

\section{(2) The Future of the Third Way}

The third round of six-party talks held in Bcijing, which are aimed at resolving 
the nuclear crisis, ended with the adoption of an eight-point chairman's statement (June 26, 2004). Although the U.S. and the two Koreas presented theit positions in a clearer fashion during this round of talks than in the previous two such meetings, it is evident that this process will be a long and arduous one. At the international seminar held in South Korea to commemorate the fourth anniversary of the 6-15 North South Joint Announcement, the representatives of the North Korea, which has demonstrated a more cordial attitude toward che international community since the Ryongcheon incident, demanded that: I) The already agreed-upon projects be implemented, 2) cooperation be expanded to the light industry, infrastructure, and high technology sectors, 3) inter-Korean conperation be expanded to include improvements to the North's cconomic infrastructure, t) the surrounding countries provide more support and adopt a cooperative attitude in order to assure that inter-Korean economic projects come to fruition (Min 2004).

Given that North Korca is known to have lobbied China to increase economic cooperation during Kim Jong-Il's visit to China in April 2004, the above-mentioned demands can be construed as the North reaching out to the other major powers surrounding the Korean peninsula, which as mentioned earlier have become the North's biggest sources of economic resources, and asking for their support in developing the North Kotean exonomy in the aftermath of the Economic Management Improvement Measures. Will North Korca be successful in this endeavor? As it is still too carly to carry out a comprehensive evaluation of Kim Jong-Il's economic policy, which is based on a 3rd way, any prediction of the future dircction of his economic policy will by nature be inconclusive. Nevertheless, the following scenarios are the most likely:

The first such scenario is one in which although the normalization of U.S-North Korea relations remains elusive, because of their inability to resolve the pending issues during the six-party talks, North Korea still manages to secure approximately the same amount of economic resources from South Korea and China as it is currently getting. In such a scenario, while the North Korean system would remain intact, Kim Jong-Il's socialist economic policy would have to resolve problems such as inflation, the loosening of the planned economy, a problem which has arisen as a result of the growing cconomic polarization, and the expansion of the economically marginalized group, including the urban poor (Cha $2004, \mathbf{1 7}$ ). In order to resolve these problems, Kim Jong-Il may bave to make a strategic choice between further strengthening the military-first politics and expanding the operational spaces of the market economy. However, under this scenario the possibility that the North Korean economy may undergo the same kind of "Big Bang" transformation that occurred in Russia and Eastern Eutope cannot be ruled out.

The second scenario is one in which following the successful conclusion of the six-party talks, an agreement similar to the Geneva Agreement is reached. Should this come to pass, Kim Jong-]l's socialist third-way would in all likelihood, after many twists and tums, succeed. Under such a scenario, inter-Korean economic cooperation 
is expected to accelerate, with an increasing amount of Japanese and other foreign capital being invested in the North Korean market. Moreover, North Korea could also gain increased access to international financial organizations. As far as the-North's special economic zones are concerned, it is expected that under such a scenario, these would experience more rapid reform and opening than was the case in China by reaping the benefits of late development.

In the case of the North's regular areas, the speed of reform and opening would remain to some degree regulated. However, internationally such a denouement will depend on how the conflicts over the speed of the North's reform and opening policy are resolved, while domestically the issue of how smoothly the planned economy is run will loom latge.

The chird scenario is a Libyan-style one in which North Korea abandons its nuclear program and agrees to unconditional inspections of its suspected nuclear facilities. This scenario is based on the assumption that North Korea would gain concessions in secret negotiations with the U.S. However, given North Korea's mistrust of the current U.S. administration, and the North's emphasis on the primacy of the military, such a scenatio is unlikely at this point.

\section{CONCLUSION}

Although Kim Jong-Il has finally begun to implement his economic policy after a long preparation period, this economic policy has to date failed to meet expectations; an assertion supported by a simple look at North Korcan economic indicators during this period. However, as economic reforms are ongoing, for example the development of the Sinuiju Special Administrative District has not yet begun; it is too early to evaluate Kim Jong-Il's economic policy. The characteristics of the North Korean economy in the aftermath of the Economic Management Improvement Measures can be summarized as follows: an increased number of operational spaces for the market cconomy have been introduced within the North Korcan econumy; the gencral perception of capitalism has been improved as such notions as the necd to achieve a balance between supply and demand, efficiency, and production-based distribution have become more widely accepted. Although there remain many problems for North Korea to resolve, such as the construction of the infrastructure needed to assure the development of special economic zones such as the Geumgangsan tourism district, Gaeseong Industrial Complex, and Sinuiju Special Administrative District, it is evident that the North has gone to great lengths to assure that the mistakes that have been made in connection with the development of the Rajin-Sonbong Free Economic Trade Zone opened in 1991, are not repcated.

What will the North Korean economy look like a decade from now? The current state of the North Korean economy makes certain things clear. Although predictions of how the quantitative aspects of the North Korean economy will change are difficult 
to form, there is general agreement that the North Korean economy will increasingly move towards a market-oriented one. In other words, regardless of whether $\mathrm{Kim}$ Jong-Il's socialist third way succeeds or not, the market economy has already begun to expand into the mainstream of the North Korean economy, an argument that is supported by the changes that have taken place in North Korea since the Economic Management Improvement Measures.

\section{REFERENCES}

Bae, Chong-Ryel. 1995. North Korca's Global Economic Policy and Inter-Korean Fconomic Exchanges, Legislative Report 234, National Assembly Library Legislative Research Division. August.

Bae, Chong-Ryel. 2000. Evaluation of North Korea's Policy to Attract Foreign Investment in the Rajin-Sonbong Free Economic Trade Zone and Future Outlook. In North and South Korean Economic Cooperation; Development Strategy and Policy Measures, ed. Bae Chong-Ryel and Park Yoo-Hwan. Seoul: The Export-Import Bank of Korea. Bae, Chong-Ryel. 2003. Tasks Related to the North's Reform Efforts Undertaken as Part of its Economic Management and Devclopment Strategy. In Present State of North Korea's Economic Reforms and the Role of the Two Koreas and the International Community, ed. Cho Myung-Chul ct al. Seoul: Korea Institute for International Economic Policy.

Cha, Victor. 2004. North Korea's Economic Reforms and Security Policy. KDI Review of the North Korean Economy 6 (4). Seoul: Korea Development Institute.

Cho, Dong-Ho. 2004. Perspectives on the Changes in North Korea's Economic Policy and the Role of North-South Economic Cooperation. KDI Review of the North Korean Economy 6 (2). Seoul: Korea Development Institute.

Chosun Shinbo. 2002. Higher and Faster, at the Site of Economic Reconstruction -11-: The Key to Economic Reconstruction as Seen by Economists, November 22.

Chosun Shinbo. 2003. Primary Focus on the Development of the Defense Industry, Economic Strategy to Prepare for the Upcoming War between the U.S. and North Korea, April 11.

Jeong, Se-Hyun. 2004. Speech Given at the Open Unification Forum. May 12. Kang, Il-Choon. 2003. 7-1 Economic Management Improvement Measures: An Evaluation and Reinterpretation. 7-1 Economic Management Improvement Measures: Evaluation and Future Perspectiver. The Fourth International Seminar Organized by the Institute of North Korean Studies, Korea University. June 26.

Kim, I-Sung. 1990. The Problems Associated with the Management of a Socialist Economy VI. P'yongyang: 'The Workers Party of Korea Publishing House.

Kim, II-Sung. 1996. Complese Collection of Kim IL-Sung's Works 44 (December 1992-July 1994). P'yongyang: The Workers Party of Korea Publishing House. 
Kim, Jong-Il. 2000. The Selected Works of Kim Jong-1l 14. (1995-1999). P'yongyang: The Workers Party of Korea Publishing House.

Kim, Jong-Ki. 1994. Northeast Asian Economic Cooperation and North Korea's Economic Strategy. NCNA International Academic Forum, Shenyang, China.

Kim, Kyung-1l. 2003. Implications of North Korea's Economic Management Improvement Measures and Futurc Prospects. Evaluation of the Ecomomic Management Improvement Mecsiures and Future Propgets. The 1th International Academic Seminar, North Korca Research Conter, Korea University.

Kim, Woon-Keun. 2003. Present State of Agricultural and Fishing Areas in North Koren and the Region and Class-based Gap in the Food Distribution System. Agricultume in Nonth Korea During the Transitional Period; Present State of Agricultural and Fishing Arear and Potential Countermeasures. Seminar Held by the National Agriculture and Fisheries Research Institure and Korea Peninsular Agro-Fishery Policy Research Institutc.

Kim Yong-Ho. 2004. Important Issues Related to the Encouragement of the Creativity of Entcrprises, while Ensuring the Government's Continued Central Guidance. Kim Il-Sung University Gazttte, The 93rd Year of Juche 50 (1): 39-41.

Korean Contral New Agency. 2000. 'The U.S. Government I'akes Steps to Ease Economic Santions. July 1.

KOTRA. 2004. Can the North Korean Economy Become a Market-oriented One? Katra's Repart on the North Korean Economy.

Kwon, Yeong-Kyung. 2003. Tasks Related to the Direction of the Reform of the Economic Management System. In Present State of North Korka's Economic Reforms and the Role of the 'Two Koreas and the International Community, ed. Cho Myung-Chul et al. Seoul: Korea Institute for International Economic Policy.

Lee, Chan Woo. 2003. 7-1 Economic Management Improvement Measures: A Comparison with the Reform in China in the 1980's. 7.I Economic Management Improvement Mcasure.: Evaluation and Future Perspectizes, lihe lourch International Seminar Organized by the Institute of North Korea Studies, Korca University. June 26.

Lee, Jong-Hyuk. 2004. The Participatory Government and the Private Sector: Why so Many Problems? International Conference to Commemorate the 4th Anniversary of the June 15 Joint Declaration. Kim Dae-Jung Library of Yonsei University, Korca Institute for National Unification, Research Institute of Korean Unification.

Lim, Hyun-Jin and Jeong,Yeong-Chul. 2004. North Korea's Economic Reforms: Toward Capitalism? Modem North Korea 7 (1). The Graduate School of North Korean Studies, Kyungnam University.

Masau, Okonogi. 2001. The Dilemma of North Korea's Military-First Politics, Workt Affairs Weckly Magazine. June 6 and 13 (Translated).

Min, Gum-Sung 2004. The Ditection of the Development of Inter-Korcan Economic Coopcration and Future Tasks. Intemational Confenence to Commemonate the 4th Anniversaty of the June 15 Joint Declaration. Kim Dae-Jung Library of Yonsci University, Korea 
Institute for National Unification, Rescarch Institute of Korcan Unification.

Nakagawa, Masahiko. 2003. Formation of the Yeonhap Giupso in North Korea. KDI Reriew of the Nonth Korean Economy: 5 (3). Seoul: Korea Development Institute. Nam, Song-Wook and Mun Seong-Min. 2000. Estimation of the Size of North Korea's Market Economy: With a special focus on the year 1998. Modern Nortb Korea 3 (1). Kyungnam: Kyungnam University.

Natsios, Andrew. 1999. The Politics of Farnine in North Korea, Special Report. United States Institute of Peace.

O, Wonchol. 1995. Nonth Korea's Economic Polizy. Scoul: Kia Economic Rescarch Institute. Park, Hyung-Jung. 2004. State of Practical Socialism as seen from the Standpoint of Comparative Socialism and Future Prospects. The North Korean Exonmy During the Finst Decade of the Kim Jong-ll Regime. Academic Conference Hcld by the Korea Institute for National Unification.

Park, Seok-Sam. 2002. The Private Economy in North Korea-Estimation of the Size of the Private Economy: Currency circulation, and out of Circulation Foreign Currency. Seoul: Bank of Korea.

Shambaugh, David. 2003. China's Long-Term Strategy Toward North Korea. KDI Revieu of the North Korean Economy 5 (4). Seoul: Korea Development Institute. Washington Post. 2004. Sprouts of Capitalism Emerge from the Cloud of Dust that is North Korea (Munhwa Ilbo and Kyunghyang Newspaper, reprinted on May 21).

\section{ENDNOTES}

1 For example, the economic officials in charge of the formation of these Yeonhap Giupso, in keeping with the expansion of trade policy adopted by the Party and Statz: Council, attempted to give: them more rights to engage in trade. However, their efforts came to naught as a resulc of the objections of Kim Il-Sung. Masahiko Nakagawa, Ibid, p.70

$2 \mathrm{Nam}$, Song-wook and Mun Scong-min have estimated this amount to be a whopping $27.1 \%$ of the overall ecotiomy. 